rates for new cases of schizophrenia, that many, if not most, new patients are being treated in the community with neuroleptics. On occasion I have come across young schizophrenics treated inappropriately by their GPs with minor tranquillisers alone. Personal experience also suggests that treatment with major tranquillisers is sometimes, if not indeed often, initiated by non-hospital doctors, and I have recently seen several new epileptics being started on phenobarbitone by their GPs without referral to a neurologist. This is also the experience of several other psychiatrists I have spoken to.

Again, the GP as primary care physician may be called in to deal with a dystonic crisis and should therefore be familiar with drugs such as procyclidine and orphenadrine. I have, however, encountered several cases of patients with extrapyramidal reactions being admitted to hospital because the GP was not familiar with a more specific antidote than diazepam: it is unusual for GPs to carry an intramuscular anticholinergic in their emergency bag.

I understand that the "ban" on advertising these essential drugs to GPs is not so much recommended by the product licensing authority as dictated by commercial considerations. In some cases company representatives expressed surprise that there might be a market among GPs; others suggested that it might be inappropriate for GPs to assume the initiative in treating epileptics or schizophrenic patients. None seemed to appreciate the fact that such treatment is sometimes begun by GPs. Certainly neuroleptics and anticonvulsants are no more intrinsically dangerous than antiasthmatic or cardioactive agents, treatment with both of which may be started by the GP.

Surely the companies could only benefit from the large GP sector knowing about their products. And from the patient's viewpoint, who is better placed than his properly informed GP to deal with side effects or changes in dose, which otherwise may have to wait until the next hospital appointment ? Again, I am sure many patients remain on old fashioned, more toxic drugs for long periods because the GP's knowledge of new therapies remains scanty.

It is quite understandable that well known haematinic drugs or esoteric antineoplastic agents are not actively promoted to GPs, but surely it is time for the drug companies to update their marketing policies on important antipsychotic and anticonvulsant agents.

H G KINNELL

Botleys Park Hospital,

Chertsey, Surrey

\section{Hyperviscosity syndrome in IgE} myeloma

SIR,-Dr S J Proctor and his colleagues describe a patient with IgE myeloma using the terms "clinical hyperviscosity" and "classic hyperviscosity syndrome" (27 October, $p 1112$ ). The hyperviscosity syndrome, however, is ill defined. The term was introduced to describe a state in which in vitro blood and plasma viscosities are abnormally high. ${ }^{1}$ As such it is not a syndrome but a laboratory finding. Hyperviscosity may lead to symptoms such as retinal changes and neurological, cardiovascular, and psychiatric abnormalities as well as a bleeding tendency and general signs of illness in various diseases. ${ }^{2}$ The association, however, is loose. It is not possible to predict clearly symptoms from abnormal rheological values or vice versa. ${ }^{1}$ This has led to the widely accepted opinion that the term "hyperviscosity syndrome" is obsolete. Whether or not this is true, it should not be diagnosed without measuring viscosity. Hence it may be likely, but it is not certain, that Dr Proctor and his colleagues were dealing with a patient presenting a set of clinical features caused by abnormal blood rheology.

\section{E ERNST}

Haemorheology Research Unit, University Clinic,

1 Fahey JL. Serum hyperviscosity syndrome. JAMA 1965;192:464-7.

Ernst E. Klinik der Hyperviskositäts-Syndrom. Med Klin 1982;77:144-6.

\section{Common bacterial pathogens and} resistance to antibiotics

SIR,-Many patients with head injuries involving fractures through ear or air sinuses are admitted each year to the orthopaedic or general surgical beds of district general hospitals. Standard management includes a short course of sulphonamides as prophylaxis against pharynx derived meningitis. ${ }^{2}$ In his leading article (15 September, p 638) Dr P J Sanderson says that "increasing resistance to sulphonamides now prevents the use of these drugs in initial treatment" of meningitis. Does this hold for prophylaxis as well as for treatment and, if so, should we now alter our approach ?

Bristol Royal Infirmary

M J KeLLY

Bristol BS2 8HW

Ellis $\mathrm{H}$, Calne RY. Lecture notes on general surgery. 6 th ed. Oxford: Blackwell, 1983:11

Way $\mathrm{LW}$, ed. Current surgical diagnosis and treatment. 6th ed. California: Lange Medical Publications, 1983:761.

${ }_{*}^{*}$ Dr Sanderson replies below.-ED, BMF.

SIR,-Mr Kelly raises an important topic, but the sentence he quotes referred to the early treatment of Neisseria meningitidis meningitis. Prophylaxis for meningitis after head injury requires cover against, most commonly, Streptococcus pneumoniae, Haemophilus in fluenzae, and Staphylococcus aureus and less often anaerobes, coliforms, and other organisms. The increase in resistance of $N$ meningitidis to sulphonamides is therefore less relevant, but there is some evidence of increasing resistance to both this drug and chloramphenicol by $H$ influenzae ${ }^{123}$ and in some areas by $S t r$ pneumoniae. ${ }^{4}{ }^{5}$ Moreover, when the meninges are uninflamed sulphonamides in general enter the cerebrospinal fluid ${ }^{6}$ and brain ${ }^{7}$ in lesser amounts than chloramphenicol, which penetrates better than any other antibacterial agent. With the drug concentrations achieved, sulphonamides are less active than chloramphenicol against the predominant organisms mentioned (table).

Although chloramphenicol has serious side effects, these bacterial advantages suggest an increasing role for this drug in preventing meningitis in fractures of the skull affecting the air sinuses or nasopharynx or complicated by leaks of cerebrospinal fluid.

Edgware General Hospital

Edgware, Middlesex HA8 OAD

1 Williams JD, Andrews J. Sensitivity of Haemophilus influenzae to antibiotics. Br Med $\mathcal{F} 1974 ; \mathrm{i}: 134-7$. Howard AJ, Hince CJ, Williams JD. Antibiotic resistance in Streptococcus pneumoniae and resistance in Streptococcus pneumoniae and 3 Philpott-Howard J, Williams JD. Increase in antibiotic resistance in Haemophilus influenzae in the United Kingdom since 1977: report of study group. Br Med F 1982;284:1597-9.

4 Linares J, Garau J, Dominguez C, Perez JL. Antibiotic resistance and serotypes of Streptococcus pneumoniae from patients with community acquired pneumococcal dise

5 Ward JIher 1983;23:545-7is

Ji. Antibiotic resistant Streptococcus pneuMev Infect Dis $1981 ; 3: 254-65$.

6 Barling RWA, Selkon JB. The penetration of antibiotics into cerebrospinal fluid and brain tissue. 7 Antimicrob Chemother 1978;4:203-27.

7 Kramer PW, Griffith RS, Campbell RL. Antibiotic penetration of the brain. $\mathcal{F}$ Neurosurg $1969 ; 31: 295$ 302.

8 Cooksey RC, Facklam RR, Thornsberry C. Antimicrobial sensitivity patterns of streptococcus p45-8.

\section{Court come true-for better or for worse?}

SIR,-Drs Cameron Bowie and Alun Parry Jones (10 November, p 1322) outline the changes that have taken place in child health services in Somerset as a result of the implementation of the recommendations of the 1976 Court report, Fit for the Future. ${ }^{1}$ Their report sheds much light on the current debate on the organisation of these services, and it is salutary to consider some of its implications.

Few would challenge the principle that comprehensive child health services should be provided, and the Somerset experience may be useful to other districts wishing to avoid the pitfalls. O course, GPs are of fundamental importance in the health care of their child patients, but the improvements in outcome which, it is often asserted, would result from making GPs the lynchpin of the child health service have simply not materialised. Drs Bowie and Jones say that several measures of the usefulness of the service were chosen but presen data on only one, age at orchidopexy, and these indicate no significant improvement in comparison with neighbouring districts. The claimed benefits thus appear to be largely illusory.

Most of the advantages claimed are anecdotal and at times inconsistent. Thus we are told that an advantage of the scheme in rural areas is that

Comparison of sensitivities to chloramphenicol and sulphamethoxazole. Results are numbers (and percentages) of strains

\begin{tabular}{|c|c|c|c|c|c|c|}
\hline & \multicolumn{3}{|c|}{ Chloramphenicol } & \multicolumn{3}{|c|}{ Sulphamethoxazole } \\
\hline & Total & Sensitive & Resistant & Total & Sensitive & Resistant \\
\hline $\begin{array}{l}\text { Haemophilus influenzae* } \\
\text { Streptococcus pneumoniae } \\
\text { Staphylococcus aureus }+\end{array}$ & $\begin{array}{r}235 \\
96 \\
324\end{array}$ & $\begin{array}{l}216(92) \\
67(70) \\
323(97 \cdot 7)\end{array}$ & $\begin{array}{c}19(8 \cdot 0) \\
29(30) \\
1(0 \cdot 3)\end{array}$ & $\begin{array}{r}105 \\
96 \\
368\end{array}$ & $\begin{array}{r}51(49) \\
0 \\
262(71)\end{array}$ & $\begin{array}{r}54(51) \\
96(100) \\
106(29)\end{array}$ \\
\hline
\end{tabular}

*Breakpoint for sensitive strains = minimal inhibiting concentration of $<2.0 \mathrm{mg} / 1$ for both drugs. Figures from ref 3 Breakpoints as above. Figures adapted from ref 8 . $\ddagger$ Disc test sensitivities of strains isolated at Edgware General Hospital, January-October 1984 